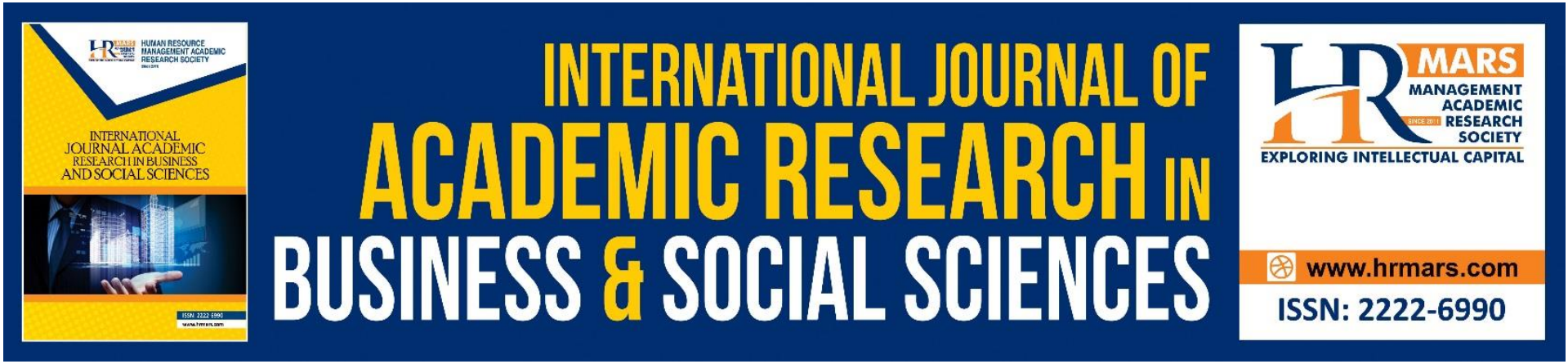

\title{
A Systematic Literature Review on Impact and Challenges in the Implementation of Online Learning among Accounting Teachers and Students
}

\section{Nor Idayu Azmi, Suhaida Abdul Kadir, Arnida Abdullah \& Siti Noormi Alias}

To Link this Article: http://dx.doi.org/10.6007/IJARBSS/v12-i2/12290

DOI:10.6007/IJARBSS/v12-i2/12290

Received: 12 December 2021, Revised: 16 January 2022, Accepted: 01 February 2022

Published Online: 19 February 2022

In-Text Citation: (Azmi et al., 2022)

To Cite this Article: Azmi, N. I., Kadir, S. A., Abdullah, A., \& Alias, S. N. (2022). A Systematic Literature Review on Impact and Challenges in the Implementation of Online Learning among Accounting Teachers and Students. International Journal of Academic Research in Business and Social Sciences, 12(2), 398-412.

Copyright: (c) 2022 The Author(s)

Published by Human Resource Management Academic Research Society (www.hrmars.com)

This article is published under the Creative Commons Attribution (CC BY 4.0) license. Anyone may reproduce, distribute, translate and create derivative works of this article (for both commercial and non0-commercial purposes), subject to full attribution to the original publication and authors. The full terms of this license may be seen at: http://creativecommons.org/licences/by/4.0/legalcode

Vol. 12, No. 2, 2022, Pg. $398-412$

Full Terms \& Conditions of access and use can be found at http://hrmars.com/index.php/pages/detail/publication-ethics 


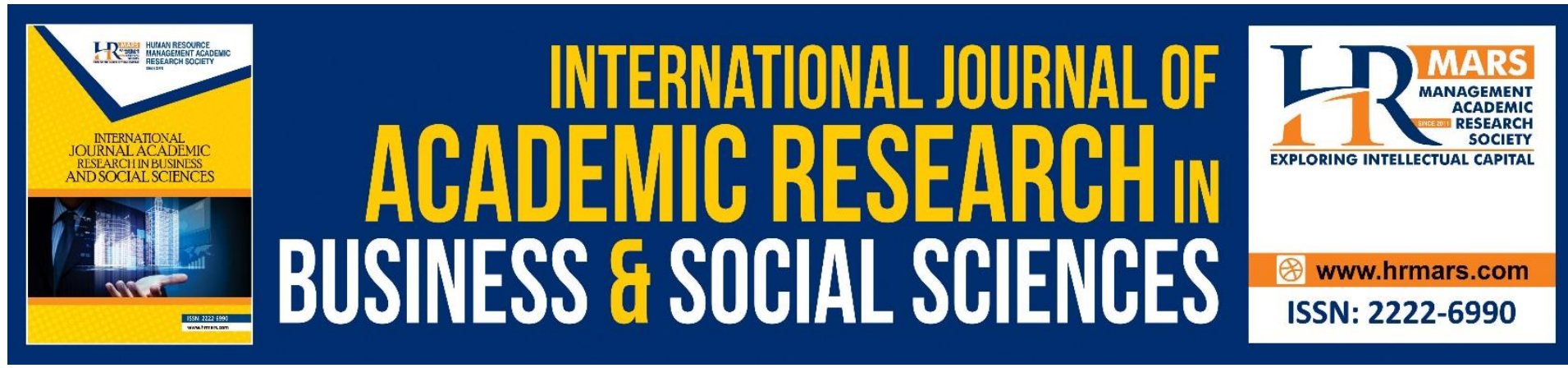

\title{
A Systematic Literature Review on Impact and Challenges in the Implementation of Online Learning among Accounting Teachers and Students
}

\section{Nor Idayu Azmi, Suhaida Abdul Kadir, Arnida Abdullah \& Siti Noormi Alias}

Faculty of Educational Studies, Universiti Putra Malaysia, Serdang, Malaysia Corresponding Authos: idayuazmi_90@yahoo.com, suhaida@upm.edu.my

\begin{abstract}
Teaching and learning utilizing electronic resources has become more prominent. The implementation of online learning in accounting has had an impact and created challenges for students and teachers alike. The purpose of this systematic literature review is to identify the impact and challenges faced by them in implementing online learning of accounting. Surveys on articles were conducted between 2017-2021 using three databases namely ERIC, Mendeley and Scopus. The findings show that online learning had no negative impact on teachers and only shows positive impact in the easy delivery of lessons by teachers. Technology makes the learning process orderly. Positive impact was noted among students too, in terms of improvement in the achievement of the subject and a positive attitude towards it. The negative impact of online learning implementation is that there are students who are stressed because they are less interested in using different learning approaches which slates towards traditional methods. Among the challenges in the implementation of online learning of accounting by students are the lack of technological devices as well as limited access to computers and the internet. While the challenge for teachers lies in the lack of knowledge and skills in executing online learning. Various programmes or workshops need to be designed to enhance skills and improve confidence while implementing online learning of accounting among teachers and students.
\end{abstract}

Keywords: Impacts, Challenges, Online Learning, Accounting Teachers, Online Accounting Education

\section{Introduction}

Accounting is one of the principal subjects in the field of Technical dan Vocational Education. It will be essential for accounting students to build their prowess in this field for various reasons. The goal and objective of accounting at the secondary level is to produce individuals who are knowledgeable and skilled in accounting, accountable, critical and reflective thinking, skilled in the use of information technology and who have good communication skills through a meaningful learning approach based on the integration of accounting theory and practice. 
Further, that student would be able to make decisions, sensitive to its effects, be responsible and is able to apply knowledge in the way of career and life based on the Curriculum and Assessment Standards Document (Malaysia Education Ministry, 2016). These days, the education system encourages teachers to integrate the use of technology in education while increasing their awareness in the application of this technology within the process of teaching and learning. Education today has undergone rapid changes in line with current technological advances. What used to take place physically in the classroom, now has transitioned into flexible methods using electronic devices. Online learning is a new method in teaching that allows a teacher-centered approach to be transformed into student centered approach indirectly. The quality of online teaching and learning can be improved through the application of technology in addition to the use of internet as a medium teaching and learning process conducted (The \& Usagawa, 2018).

Online learning is in line with the strategy outlined in Education Development Plan Blueprint (2013-2025) in its seventh shift which encourages the use of Information and Communication Technology (ICT) to improve the quality of learning in Malaysia by increasing the use of the internet and virtual learning, leveraging the use of ICT in self-based learning including distance learning (Malaysia of Education Ministry, 2013). The implication of online learning in the process of teaching and learning is to facilitate teachers and students in providing a wider range of learning opportunities. Furthermore, it is used to support the traditional learning process vis-a-vis face-to-face. In addition, online learning allows teachers or instructors to deliver their instruction and knowledge to students in large numbers without being tied to limited space and time.

The use of technology in accounting teaching and learning is able to help teachers and students to better perform in calculation, using effective methods, analyse data and increase the opportunities to explore accounting concepts more easily. These are favourable methods to teaching and learning accounting. Accounting teachers need to use the relevant application and software as often as possible, so that students will get better understanding and improve their performance in Accounting rather than rely on memorization techniques (Rahman et al., 2019). Past research on online accounting education has focused on online applications. Among the specific applications of accounting are online tutorials used for the accounting cycle learning and problem solving Zhang et al., (2020), mobile apps technology which is an online mobile technology application for students who do not have an accounting background (Madah et al., 2020) and the use of online learning tools that give students the opportunity to try a variety of possible solutions quickly for learning accounts (Herrador-Alcaide et al., 2020). The use of these online applications in the market nowadays are very limited and not compatible with accounting for all education levels.

The use of mobile devices like mobile phones, lap top and tablets will enable learning to be carried out regardless of place, time and is flexible by providing opportunities for teachers and students to explore knowledge (Malan, 2020). There are several issues regarding online teaching and learning that were also identified. Similar problems or difficulties were faced in institutions of higher education because there are students who tend to use the traditional method, which is still relevant to current times. Also, the difficulties encountered involve implementation matters due to the lack of technological facilities (Ali et al., 2020), lack of skills to ensure effectiveness of online implementation between teachers and students 
(Skhephe et al., 2020), unpreparedness of teachers and students while using the tools and application (Alshurafat et al., 2021) and technical problem while using the computer (Grabinski et al., 2020). With the intensified use of applications related to the teaching and learning of accounting online, several impacts were observed. Yet, to achieve progressive outcomes, various challenges need to be given attention to. This research was conducted to identify the impact or effectiveness in the implantation of online teaching and learning of account through teachers' and students' perspectives and the challenges that they faced while carrying out online accounting using electronic devices.

Although there are various studies related to online education, especially at the tertiary level, however, there is a limited comprehensive study related to the process of online teaching and learning in the field of accounting education. There have been reviews related to the process of online teaching and learning at the highest level which is tertiary (Macias et al,. 2021; Braun et al., 2020; McCarthy et al., 2019) that relates to the pedagogical medium that has been used either face to face, online and blended learning. Pedagogy refers to the way students deliver the content and the way students present and learn be it the fully online strategy, complete face to face connection or combination of both which is blended teaching and learning. However, the reviews are more focused on theory and not on the impact and challenges of the process of online teaching and learning. Therefore, the purpose of this article is to create a systematic literature review on the impacts and challenges faced by teachers and students while implementing online accounting. There are two research questions that will be addressed in this article:

1) What are the impacts of the implementation of online accounting education among teachers and students?

2) What are the challenges faced by teachers and students in the implementation of online accounting education?

\section{Methodology}

Mallett et al (2012) stated that by using a systematic literature review, the results for the literature would highlight valuable elements because they are more extensive, increased in transparency and would emphasize the importance of empirical evidence. The procedure conducted in this article is summarized using the PISMA flowchart as proposed by (Shaffril et al., 2020). It creates a systematic, accurate and reliable overview. The search engines used in this article are ERIC, Mendeley and Scopus. Findings included have been streamlined to those in the last 5 years $(2017$ - 2021). Khan et al (2003) suggested the following 5 steps in systematically implementing literature highlights.

\section{Step 1: Framing Questions for Review}

Research questions were developed before a systematic review was conducted on selected journal articles. All selected journal articles are related to the challenges and impacts of implementing online accounting education that relates closely to the process of teaching and learning. The challenges and impacts of the online accounting process takes into account, input from teachers and students because both of the subjects are directly involved in it. Learning via electronic in this journal also relates to various terms like virtual learning, webbased learning, distance learning, mobile learning and blended learning. While, in conclusion it involves all types of learning that uses online applications as teaching pedagogy to deliver contents and materials to students. 


\section{Step 2: Identifying Relevant Work}

The systematic literature review method is implemented starting with screening, eligibility and inclusion as proposed by Mengist et al., (2020). At this stage, the process of identifying journal articles that meet the criteria was carried out. The search engines used to find related articles were Mendeley, Scopus and ERIC. The main keywords used are "online accounting education", title: (barrier OR challenges OR impact OR effectiveness) AND using e-learning in "accounting education" serta (barrier OR challenges OR impact OR effectiveness) AND online learning AND ("accounting education"). The use of AND into the keywords is to diversify the broad findings and broaden the search on the challenges and impacts of accounting online education among teachers and students. Table 1 shows the study search strings for Scopus, ERIC and Mendeley.

Table 1: Search string

\begin{tabular}{ll}
\hline Database & \\
\hline Scopus & TITLE-ABS-KEY ((“Online Accounting Education OR “Online Learning” \\
& OR “Accounting Education”) AND ("Barrier OR Challenges OR Impact \\
& OR Effectiveness”)) \\
ERIC \& Mendeley & "Online Accounting Education”
\end{tabular}

\section{Step 3: Assessing the Quality of Studies}

Journal articles that were selected had gone through several screening levels using ERIC, Mendeley and Scopus as search engines. There are various journal articles based on the keywords that have been featured. However, only related journal articles that met all the criterion set by the researcher were selected. Articles included, were those related to the impacts and challenges in the implementation of online accounting education faced by educators and students. It is suitable for answering the research questions that have been posed. Although there are several journal articles that meet the scope of this research, the use of foreign languages other than English and Malay has resulted in some articles being excluded. A selection of articles contained only empirical studies. Table 2 shows the search entry selection criteria. This study not only involved the impacts and challenges of online accounting education for the context of Malaysia but assessed the quality of teachers and students from all over the world. Challenges and impacts are limited to the teachers and students who were involved in the process of teaching and learning the accounting subject.

Table 2: Inclusion Criteria

\begin{tabular}{ll}
\hline Criteria & Inclusion \\
\hline Year & $2017-2021$ \\
Journal type & Journal \\
Article type & Open access \\
Language & English \& Malay \\
Field & Accounting \& Accounting Education \\
Research type & Empirical research \\
Scope & Impacts and Challenges of Accounting teachers and students \\
\hline
\end{tabular}




\section{Step 4: Summarizing the Evidence}

Data was analyzed systematically based on the criteria set in step 3. The content of the article was related to the impacts and challenges faced by teachers and students that was reviewed and critically analysed. There are the number of articles discussing online accounting education. Based on the specified keywords, searches were made through Mendeley, ERIC and Scopus databases and a total of 32 articles were obtained [Mendeley $(n=17)$; ERIC ( $n=$ $5)$; Scopus $(n=10)$ ]. The articles were then screened based on criteria such as the year of publication since 2017 to 2021 and the type of publication - journals.

Thereafter, the selection of the most relevant journal articles related to the impacts and challenges of online accounting education, related to the process of teaching and learning, was done in more detail by screening the titles and abstracts to eliminate irrelevant articles. The number of filtered articles was 20 [Mendeley $(n=9)$; ERIC $(n=2)$; Scopus $(n=9)$ ]. These articles were evaluated based on more specific criteria that related to accounting and its empirical studies. Using Malay or English and the discussion on impacts and challenges of online accounting that were in line with research questions posed, ensued. Based on the analysis of articles conducted, there were15 articles that met all the criteria set, articles obtained through $(n=5)$, ERIC $(n=2)$ and Scopus $(n=8)$. All 15 articles went through a synthesis process to obtain the data needed to answer the research questions. The searching process is summarized using Figure 1: PRISMA flow chart.

Figure 1: PRISMA flow chart

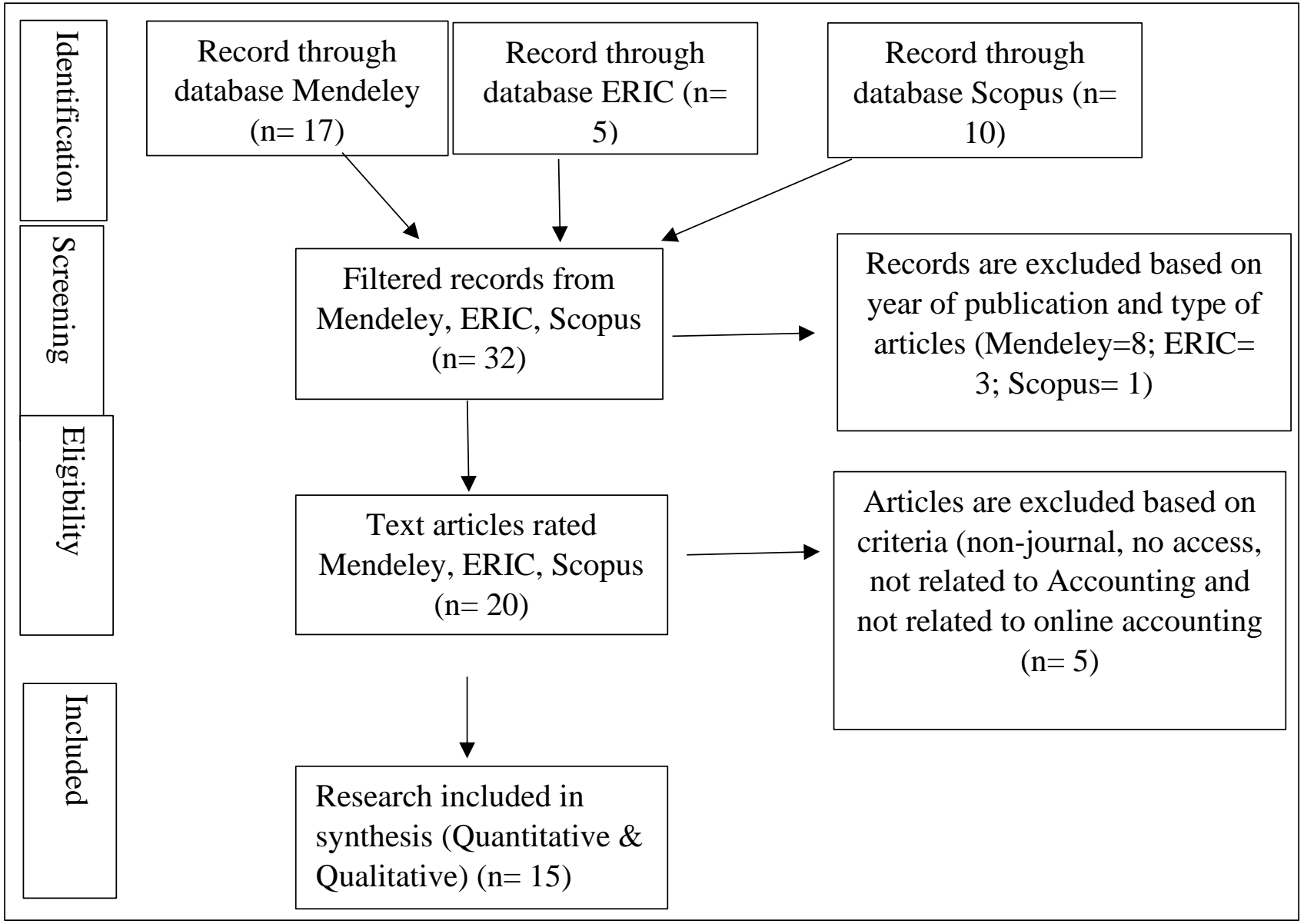




\section{Step 5: Interpreting the Findings}

The findings were summarized after all the selected articles were completed through a synthesis process based on research questions posed. There are articles that emphasized on impacts of online accounting implementation and the challenges that were faced by teachers and students. Most of the articles used quantitative methods - 12 articles, while two articles used the qualitative method and only one article used mixed methods. The summary of year published and methods used for each article is listed in Table 3. Furthermore, from the interpretation of the data performed, it clearly shows that there are two impacts of online accounting implementation which are positive impacts for teachers and students as well as challenges faced by both. The impact on students saw some negatives.

Table 3: Listing of impacts and challenges of online accounting education

\begin{tabular}{|c|c|c|c|}
\hline No. & Author & Year & Impacts and Challenges \\
\hline 1 & $\begin{array}{l}\text { Krasodomska } \\
\& \text { Godawska }\end{array}$ & 2021 & $\begin{array}{l}\text { Positive impact on students' achievement and students' } \\
\text { engagement }\end{array}$ \\
\hline 2 & Macias et al & 2021 & $\begin{array}{l}\text { Positive impact for teachers who quickly learn to use } \\
\text { technological tools, accelerating the development of online } \\
\text { teaching and learning }\end{array}$ \\
\hline 3 & $\begin{array}{l}\text { Alshurafat et } \\
\text { al }\end{array}$ & 2021 & $\begin{array}{l}\text { The positive impact on students who have high belief in the } \\
\text { usability and ease of implementation of online teaching and } \\
\text { learning }\end{array}$ \\
\hline 4 & $\begin{array}{l}\text { Grabinski et } \\
\text { al }\end{array}$ & 2020 & $\begin{array}{l}\text { Positive impact for teachers - easier delivery and more } \\
\text { orderly process. } \\
\text { Positive impact for students - social competence and } \\
\text { students' progress is more effective } \\
\text { Teachers' challenges are technical problems and constantly } \\
\text { updating learning materials. }\end{array}$ \\
\hline 5 & Skhephe et al & 2020 & $\begin{array}{l}\text { Teacher challenges are lack of knowledge and unfamiliarity } \\
\text { with using technology. }\end{array}$ \\
\hline 6 & Herrador et al & 2020 & $\begin{array}{l}\text { Positive impact for mature students and achievement on } \\
\text { having a positive attitude }\end{array}$ \\
\hline 7 & Sangster et al & 2020 & $\begin{array}{l}\text { Teachers' challenges are being unprepared and } \\
\text { inexperienced for online teaching }\end{array}$ \\
\hline 8 & $\begin{array}{l}\text { Heiser \& } \\
\text { McArthur }\end{array}$ & 2020 & $\begin{array}{l}\text { Teacher challenges in loss of student's integrity in course } \\
\text { evaluation. }\end{array}$ \\
\hline 9 & Braun et al & 2020 & Negative impact on online students' assessment. \\
\hline 10 & Malan & 2020 & $\begin{array}{l}\text { Positive impact of social and collaborative involvement from } \\
\text { students through cognitive, behavioural and emotional } \\
\text { elements. }\end{array}$ \\
\hline 11 & $\begin{array}{l}\text { Nor Farizal et } \\
\text { al }\end{array}$ & 2020 & $\begin{array}{l}\text { Teacher challenges are students prefer teacher-centered } \\
\text { pedagogy and passive learning environment. }\end{array}$ \\
\hline 12 & Ali et al & 2020 & $\begin{array}{l}\text { Negative impact because effective teaching and learning is } \\
\text { difficult to achieve. } \\
\text { Teachers challenges in involving students, stress with online } \\
\text { technology and difficult communicating with students. } \\
\text { Students' challenges are lack of computer facilities, internet } \\
\text { access issues and the home environment. }\end{array}$ \\
\hline
\end{tabular}




\begin{tabular}{|l|l|l|l|}
\hline 13 & Trabulsi & 2018 & $\begin{array}{l}\text { Positive impact on students' behaviour in online teaching } \\
\text { methods. }\end{array}$ \\
\hline 14 & Richard er al & 2018 & $\begin{array}{l}\text { Negative impact on students integrity, two-way } \\
\text { communication and effective course design. }\end{array}$ \\
\hline 15 & McCarty et al & 2018 & $\begin{array}{l}\text { Positive impact on student achievement on online compared } \\
\text { to hybrid and face to face pedagogy. }\end{array}$ \\
\hline
\end{tabular}

\section{Result and Discussion}

Based on the scope of the study, various articles related to the impacts and challenges in implementing the online process of teaching and learning were produced, covering a variety of aspects such as student engagement in online accounting education (Krasodomska \& Godawska, 2021; Ali et al., 2020; Malan, 2020), students performance (Heiser \& Mcarthur, 2020; McCarthy et al., 2019), factors and effects of online accounting education (Alshurafat et al., 2021), suitability of the tool and applications that have been used (Grabinski et al., 2020; Herrador-Alcaide et al., 2020), teaching practices for accounting education (Brands \& Elam, 2017) and pedagogical approach in accounting education (Macias et al., 2021; Braun et al., 2020; Mohammed et al., 2020; Sangster et al., 2020; Skhephe et al., 2020; Richards et al., 2019). These articles discussed on impacts and challenges faced in implementing the online process for teaching and learning related to the accounting education field.

\section{Impact on Implementing Online Accounting Education}

There are 11 articles that discussed the impact gained in the implementation of online accounting through the process of teaching and learning. Alshurafat et al (2021) identified factors that influenced pedagogical change drastically. The result of the study indicated that social beliefs influence the use of the online process of teaching and learning. There are three important factors that need to be considered towards transformational change through the online medium in order to create a successful process which are subjective norms, easy to use technology and effective convenience. Meanwhile, researcher suggest that student attitude is an important factor that influences a person's intention and behavior to implement the changes. In addition, through Malaysia Education Blueprint 2013-2025 mention that attitudes, behaviors and moral values must be demonstrated by students in order to generally show positive self-evaluation on student outcome (Malaysia of Education Ministry, 2013).

Based on National Fourth Industrial Revolution (4IR) policy, technology in education is very important to adapt the changing (Economic Planning Unit, 2017). The core changing in the process of teaching in learning is pedagogical part which is the transition from traditional approach to online learning. Scholar McCarthy et al (2019) who used an experimental design made a comparison between two accounting courses taught by the same teacher and used three different teaching methods which are the face to face, online and blended, to identify the impact on students' achievement. The results show that online and blended teaching methods have a positive and significant impact on students' achievement for both accounting courses compared to face-to-face teaching methods only. The findings are in line with the discovery of Krasodomska \& Godawska (2021) which showed a significant relationship that is also positive on student achievement. The findings can be summarized that acceptance of pedagogical changes will be more positive if the online strategy is not implemented drastically and well prepared for the transitions. 


\section{Positive Impact for Teachers}

The process of online teaching and learning has become more interesting, easy and fun (Grabinski et al., 2020). Teachers also quick to customize and make use of tools and materials in the online process (Macias et al., 2021). Instructors, especially teachers need to play an important role in adapting to pedagogical changes nowadays. Teachers need to be more open minded in the use of technology for online learning. This is because, it is a necessity and no choice for pedagogical approach to produce a balanced individual among students.

\section{Positive Impact for Students}

The positive impact identified to students has good inclination towards the accounting subject and most of the students consider that they have high generic skill like confidence in implementing online learning (Alcaide et al., 2020). Students also have a positive perception toward the role of teachers in using tools and material for online learning. There are some positive impacts for students while using online learning like improve academic achievement, increase academic engagement, be creativity and good for Higher Order Thinking Skills (HOTS). However, some students prefer the face to face approach compared to online learning or computer assisted learning (Mohammed et al., 2020). This is because the face-toface approach is traditional with the teacher being present for students to seek clarification of sorts, should the need arise (Ali et al., 2020; Mohammed et al., 2020). In addition, guidance from the teacher is needed during the activity or the pre-activity. Furthermore, feedback can be given immediately and confusions to understanding cleared, should the teacher be physically present. But, it is contrast to the findings of Trabulsi (2018) showed that a positive attitude of students toward the modern approach, using technology compared to traditional teaching approach. Students have more positive attitude towards the modern approach. The conclusion of the study shows that the modern approach is a necessity and online is not an optional nowadays from Parker et al (2021), and it is a tool to improve educational performance.

\section{Negative Impact for Students}

The implementation of online accounting also has a negative impact on students. This is because, students are less willing to use a different learning approach other than face to face. High performing students in accounting are of the opinion that online approach such as using mobile phones or lap tops is not real learning compared to the traditional methods. They understand that face to face approach is a real learning (Marzuki et al., 2020). Furthermore, there are various types of learning videos that can be used during the process of online learning. However, long learning videos that are presented online, are not student friendly. Therefore, teachers need to be wisely in choosing videos that are appropriate and able to gauge the attention and the interest of students. Besides that, Braun et al (2020) conducted a comparative study between a control group and a treatment group relating to the effect of decisions on recruitment among accounting graduates through a combination of online and traditional courses. The findings of the study showed that graduates who completed most of the courses through online learning, have issues with oral communication skills, as reported by their employers, as they lack the interactive element in their learning of the wholesome element of accounting. In addition, the interpersonal skills of the candidates are also affected, and prospective employers are also less confident towards the candidates taking up positions in the beginning stage of accounting. These findings are not in line with the findings of McCarthy et al (2019) who showed a positive impact on a student who studied online. 
However, there was no negative impact on teachers identified. This is because, teachers are constantly making improvements to the online approach despite various challenges in implementing it.

\section{Challenges in Implementing Online Accounting Education}

There are 6 articles related to the challenges faced by teachers and students in implementing the process of online teaching and learning. Some of these challenges become reason for the difficulty in implementation. These are related to teacher challenges and student challenges.

\section{Teacher Challenges - Student Engagement}

The main challenge faced by teachers are student engagement. Students have diverse and different backgrounds that cause a variety of factors to influence their engagement in the online process of teaching and learning. Students have their own difficulties like internet access instability, an inconducive home environment, lack of devices and responsibilities towards family members (Ali et al., 2020). Student engagement in the process of online teaching and learning is due to several reasons like their current environment and their resources causing the ability of each student to be limited (Norehan \& Mahaliza, 2021). Student engagement is very important especially in the implementation of the online process (Malan, 2020). Every student needs to engage collaboratively and should easily socialize through their behavior, emotions, and cognitive capabilities to create an active learning environment. The challenge for teachers is to maintain the active engagement among students and always motivate them in the online process because student engagement is not an option but it is mandatory to participate. Challenges faced by teachers with regards to student engagement causes difficulties in implementing two-way communication with students. The findings of the scholar Grabinski et al (2020) stated that communication is the main determinant that motivates the teacher in implementing the online process of teaching and learning. The best communication is two-way communication between students and teachers on a current and regular basis. Good communication makes it easier for teachers to identify the level of understanding of each student.

\section{Teacher Challenges- Technical Problem}

There are many efforts by Ministry of Education, Malaysia in promoting online teaching like Digital Educational Learning Initiative Malaysia (DELIMa), EduWeb TV, Google Classroom and others. DELIMa was launched in 2020 as a platform for all Malaysia Educational need is widely used by teachers and students (Malaysia Education Ministry, 2021). Nevertheless, the challenge for teachers is technical problems while preparing and implementing the online process of teaching and learning for students (Grabinski et al., 2020). This aspect is pertinent to those teachers who lack familiarity using computer technology and the applications. Some teachers do not have experiences in implementing the online process of teaching and learning and do not have sufficient knowledge in conducting the online process. Meanwhile, most teachers were lack information and communication technology skills to access DELIMa, EduWeb TV, Goole Classroom, Google Meet and Zoom platforms and various online methods (Norehan \& Mahaliza, 2021). In fact, the accounting subject is a complicated subject to teach via the online process as the syllabus of the lesson because difficult to explain relating between each topic and it being a connected process. According to Sangster et al (2020) most accounting teachers are more comfortable and dominant in using the face to face method compared to online teaching because easy to monitor the development of their students at 
various levels. The suggestion from previous researchers Grabinski et al., (2020) argue that the best method for teaching the accounting subject is by combining a face to face approach and the online one.

\section{Teacher Challenges - Workload}

Teachers feel stressed and pressured by changing the pedagogy, system, assessment and need to quickly adapt to the new circumstances. This may cause increase in workload because teachers are required to learn new skills quickly and must be competent as well as there more time consumed in preparing for the electronic environment. Prolonged computer use and lack of movement cause other types of stress. The study conducted by Sangster et al. (2020) found that almost all teachers believe that accounting education after the pandemic was a combined approach. This showed that it is different from before when teachers are physically present in the classroom to deliver knowledge. The findings also show that the challenges and obstacles in implementing the online teaching and learning process are reduced when overcoming the initial trepidation of online teaching and learning. Most teachers display a ready and open attitude to adapt with the changes and through difficult in the beginning but they acknowledge that it is not as difficult as expected and challenges can be met and objectives will be eventually attainable.

\section{Student Challenges - Stress}

Sangster et al (2020) found that the biggest challenge experienced by accounting students was the level of stress. Some students did not have computers, tablets or smartphone facilities and could not accept the drastic pedagogical change. Furthermore, the stress level faced by students increase related to unstable internet access that resulted in reduced student engagement. When students lack of internet access in accessing materials and communication medium, it impacts to their motivation and competence to keep up with lessons. Help and guidance from teachers and the environment is very important while implementing the online process of teaching and learning to make sure the implementation will be smooth (Macias et al., 2021).

\section{Student Challenges - Technical Problem}

The challenge faced by students are some technical problems through the online system that have been used and difficulties in accessing the systems. (Malan, 2020). There are some weaknesses and shortcomings in implementing online teaching and learning that is sufficient tools that the computer needs to help form certain parties in ensuring the smooth process and students that access by phone is also challenge because the display is very limited. Although online learning can attract the attention of students because it uses a variety of attractive graphics and interactive facilities, but most of the students prefer having teachers present to provide guidance and deliver knowledge. Therefore, the need for teachers to be present in the learning process is very important and teachers cannot be replaced by the latest technological sophistication. In sum, past researchers found that student attitudes in implementing online learning were positive. This is because, they have the opportunity to get information quickly, strive to understand the content of learning and not be tied to the environment and also time of learning. However, the results of the study from HerradorAlcaide et al (2020) showed that the role of teachers as motivators and managers for online learning, plays a very important role in creating an engaging learning environment especially students that have technical problem. This is because, student attitudes toward the learning 
content are highly relevant and have a direct relationship with the role played by teachers in preparation, planning, implementation and evaluation.

The contribution to the practice that we have learnt from the impacts and challenges in implementation of online learning is accounting teachers and students should be optimist and oriented to use the different approaches and tools in educational setting. Even in future, where the normal class are resume as usual, teachers and students should be inspiring to continue using the online methods and tools to upgrade and enhance the process of teaching and learning. Teachers utilize to choose a part from the process of teaching and learning either while the implementation or assessment part by using online. Students should be more supporting and feel free to use online tools because they will continue using it at tertiary level which mean at college or university level.

\section{Recommendation}

Most of the articles obtained involve the highest level of education which is the tertiary level. One article involved the secondary level and 14 were at the university and college level. This indicates that the use of online methods in the process of teaching and learning is very widespread at the tertiary level if compared with the secondary level. Online exposure at secondary and primary level is very limited resulting in a lack of knowledge among students and teachers while applying technology during the process of teaching and learning. The result indicate that the implementation of online methods can increase the students' involvement and indirectly improve their performance. This indicates that it is a need for schools and educational institutions to provide equipment and facilities so that information disseminated accordingly.

In the Malaysian context, as it is with most parts of the world now, the online method is popular, because of the on spread of the Covid 19 pandemic. Therefore, suggestion of the research from the context of Malaysia needs to be done to reduce the challenges that faced by teachers and students and will give more positive impacts on the national education system.

\section{Limitation}

There are some limitations in the writing of this systematic literature review. Firstly, only articles in Malay and English are included. Therefore, the conclusions of this review may be less relevant to accounting education implemented in other languages or from different backgrounds. Secondly, the writing of this article only focused on accounting education although there are various reasons why accounting education differs from other subjects. This may lead to conclusions found in other subjects related to accounting education. Thirdly, the strategies used to evaluate are related to accounting education. It is likely that not all articles were selected because related articles may be published through other bases like conference proceedings.

\section{Conclusion}

As a conclusion, the purpose of this article is to answer two research questions which are 1) what is the impact of the implementation of online accounting education among teachers and students? and 2) what are the challenges face by teachers and students in implementing accounting online? 
This study found that a variety of positive impacts experienced by teachers and students. The positive impact include the learning process becoming more interesting and can increase students' focus. It also helps in improving academic performance, student engagement, thinking skills and communication skills. While the positive impact for teachers is an increase in their self-efficacy and confidence, there is also provision of opportunities for students and teachers to explore relevant materials for the process of online teaching and learning. Indirectly, student-centred learning will take place while teachers function as facilitators in helping students to master concepts. Learning opportunities become very wide and varied. In addition, the accounting subject will become easier to master especially in terms of the basic concepts with the use of technology- graphics and online game applications.

There are various challenges faced by teachers and students. Some difficulties faced were accessing computer and materials, lack of suitable devices, lack of information retrieval skills, time constraint, technical problems and concern over the use of technology. The implementation of online accounting education can be optimized if the technological facilities work well and there is a supportive environment. In addition, exposure at the early stage of appropriate education and training should be provided to teachers and students. The efficient use of technology in online learning will give positive impact and is in line with the government's goal towards the digitization of education. This systematic literature review aims to contribute to the body of knowledge and will be able to provide light through the analysis of journal articles that relate to the impact and challenges in implementing online learning. Based on the results, this article is highly relevant given that there is still a limited systematic literature review that is focused on the online process of teaching and learning.

\section{References}

Ali, I., Narayan, A. K., \& Sharma, U. (2020). Adapting to COVID-19 disruptions: student engagement in online learning of accounting. Accounting Research Journal, 34(3), 261269.

Alshurafat, H., Al Shbail, M. O., Masadeh, W. M., Dahmash, F., \& Al-Msiedeen, J. M. (2021). Factors affecting online accounting education during the COVID-19 pandemic: an integrated perspective of social capital theory, the theory of reasoned action and the technology acceptance model. Education and Information Technologies.

Brands, K. M., \& Elam, D. A. (2017). Identifying teaching best practices for accounting courses using appreciative inquiry. International Journal of Knowledge Management Studies, 8(1-2), 54-73.

Braun, R. L., Boldt, M. N., Mauldin, S., \& Viosca, C. (2020). Accounting graduates with both online and traditional coursework: impact on hiring decisions. Accounting Education, 29(4), 340-355.

Economic Planning Unit. (2017). National Fourth Industrial Revolution (4IR) Policy. Economic Panning Unit.

Grabinski, K., Kedzior, M., Krasodomska, J., \& Herdan, A. (2020). Embedding e-learning in accounting modules: The educators' perspective. Education Sciences, 10(4).

Heiser, R. S., \& Mcarthur, D. (2020). Online accounting education : How to improve security and integrity of students ' performance assessments. Journal of Instructional Pedagogies, 24, 1-14.

Herrador-Alcaide, T. C., Hernández-Solís, M., \& Hontoria, J. F. (2020). Online learning tools in the era of m-learning: Utility and attitudes in accounting college students. Sustainability 
(Switzerland), 12(12).

Khan, K. S., Kunz, R., Kleijnen, J., \& Antes, G. (2003). Five steps to conducting a systematic review. Journal of the Royal Society of Medicine, 96(3), 118-121.

Krasodomska, J., \& Godawska, J. (2021). E-learning in accounting education: the influence of students' characteristics on their engagement and performance. Accounting Education, 30(1), 22-41.

Macias, H. A., Patiño-Jacinto, R. A., \& Castro, M. F. (2021). Accounting education in a Latin American country during COVID-19: proximity at a distance. Pacific Accounting Review.

Malan, M. (2020). Engaging students in a fully online accounting degree: an action research study. Accounting Education, 321-339.

Malaysia Education Ministry. (2016). Dokumen Standard Kurikulum dan Pentaksiran (DSKP) Prinsip Perakaunan Tingkatan 4. In Bahagian Pembangunan Kurikulum.

Malaysia Education Ministry. (2021). Laporan Tahunan 2020: Pelan Pembangunan Pendidikan Malaysia 2013-2025.

Malaysia of Education Ministry. (2013). Malaysia Education Blueprint 2013 - 2025. In Education (Vol. 27, Issue 1).

Mallett, R., Hagen-Zanker, J., Slater, R., \& Duvendack, M. (2012). The benefits and challenges of using systematic reviews in international development research. Journal of Development Effectiveness, 4(3), 445-455.

McCarthy, M., Kusaila, M., \& Grasso, L. (2019). Intermediate accounting and auditing: Does course delivery mode impact student performance? Journal of Accounting Education, 46(March), 26-42.

Mengist, W., Soromessa, T., \& Legese, G. (2020). Method for conducting systematic literature review and meta-analysis for environmental science research. Methods $X, 7$.

Mohamed Shaffril, H. A., Samsuddin, S. F., \& Abu Samah, A. (2020). The ABC of systematic literature review: the basic methodological guidance for beginners. Springer Nature, 55(4), 1319-1346.

Mohammed, N. F., Kassim, C. F. C., \& Ismail, P. M. (2020). Students' perception on pedagogical approaches and its relation to exam performance in professional accounting education. Asian Journal of University Education, 16(2), 116-130.

Norehan Mohd Nasir, \& Mahaliza Binti Mansor. (2021). Cabaran Guru dalam Melaksanakan Pengajaran dan Pembelajaran di Rumah ( PdPR ): Suatu Pemerhatian Awal Abstrak Teacher Challenges in Implementing Home Teaching and Learning (PdPR ): A Preliminary Observation Abstract Pengenalan. 6(7), 416-421.

Parker, A. G., Santos, J., \& Dancy, K. (2021). Online Isn't Optional: Student Polling on Access to Internet and Devices. Ihep.Org, 1-13.

Rahman, H. A., Jaffar, F., \& Marji, L. K. (2019). Kajian Potensi Penggunaan Aplikasi Mudah Alih Classification Of Accounts App Dalam Pendidikan Perakaunan. Journal on Technical and Vocational Education, 4(3), 162-169.

Richards, R., Stevens, R., Silver, L., \& Metts, S. (2019). Overcoming employer perceptions of online accounting education with knowledge. Journal Administrative Issues, 8(2), 70-80.

Sangster, A., Stoner, G., \& Flood, B. (2020). Insights into accounting education in a COVID-19 world. Accounting Education, 29(5), 431-562.

Skhephe, M., Caga, N. P., \& Boadzo, R. M. K. (2020). Accounting teachers' readiness for Elearning in the fourth industrial revolution: A case of selected high schools in the Eastern Cape, South Africa. Perspectives in Education, 38(1), 43-57.

The, M. M., \& Usagawa, T. (2018). Effectiveness of e-learning experience through online 
quizzes: A case study of Myanmar students. International Journal of Emerging Technologies in Learning, 13(12), 157-176.

Trabulsi, R. U. (2018). Accounting students' attitudes toward traditional and modern teaching methods: The Saudi context. Academy of Accounting and Financial Studies Journal, 22(5), $1-6$.

Zhang, T., Low, L. C., \& Seow, P. S. (2020). Using online tutorials to teach the accounting cycle. Journal of Education for Business, 95(4), 263-274. 